Environmental Biology of Fishes 63: 333-339, 2002.

(C) 2002 Kluwer Academic Publishers. Printed in the Netherlands.

\title{
Ontogenetic shifts in patterns of microhabitat utilization in the small-headed clingfish, Apletodon dentatus (Gobiesocidae)
}

Emanuel J. Gonçalves ${ }^{\mathrm{a}}$, Miguel Barbosa ${ }^{\mathrm{a}}$, Henrique N. Cabral $^{\mathrm{b}}$ \& Miguel Henriques ${ }^{\mathrm{a}, \mathrm{c}}$

${ }^{a}$ Unidade de Investigação em Eco-Etologia, Instituto Superior de Psicologia Aplicada, R. Jardim do Tabaco 34, 1149-041 Lisboa, Portugal (e-mail: emanuel@ispa.pt)

${ }^{\mathrm{b}}$ Instituto de Oceanografia, Faculdade de Ciências da Universidade de Lisboa, R. Ernesto Vasconcelos, 1700 Lisboa, Portugal

${ }^{\text {c } P a r q u e ~ N a t u r a l ~ d a ~ A r r a ́ b i d a, ~ I n s t i t u t o ~ d a ~ C o n s e r v a c ̧ a ̃ o ~ d a ~ N a t u r e z a, ~ P r a c ̧ a ~ d a ~ R e p u ́ b l i c a, ~} 2900$ Setúbal, Portugal

Received 15 December $2000 \quad$ Accepted 18 September 2001

Key words: cryptobenthic fish, north-eastern Atlantic, depth distribution, rocky substrates

\section{Synopsis}

The patterns of microhabitat utilization by the clingfish Apletodon dentatus were investigated, based on SCUBA diving surveys at the Arrábida Marine Park (Portugal). In all inspected microhabitats, this species was only found in algal turfs, sea urchins and boulders. The association of $A$. dentatus with sea urchins is here analysed for the first time. There was a differential utilization of the microhabitats, with small juveniles recruiting to algal turfs, intermediate individuals found in association with the sea urchins Paracentrotus lividus and Sphaerechinus granularis and larger fish occurring mainly in boulders. The depth distribution patterns are also analysed.

\section{Introduction}

The patterns of microhabitat distribution in small cryptobenthic fishes (sensu Miller 1979) of the temperate regions have been poorly studied when compared to tropical environments. Although there are some studies on species of the north-eastern Pacific (e.g. Stephens et al. 1970, Lindquist 1985, Daniels 1987, Norton 1991) and north-eastern New Zealand (Jones 1988), the eastern Atlantic and Mediterranean cryptobenthic fauna has been scarcely investigated (but see Zander 1980, Patzner \& Santos 1992, Hofrichter 1995, Gonçalves et al. 1996, 1998, Hofrichter \& Patzner 1997, 2000, Kovacic 1997, Faria et al. 1998, Faria \& Almada 1999, Patzner 1999a,b).

The Gobiesocidae are widely distributed along temperate and tropical regions (Briggs 1955), occupying a great variety of habitats and generally occurring in very specific microhabitats such as: (i) boulder fields: Aspamichthys ciconiae and Aspasma minima (Shiogaki \& Dotsu 1972), Conidens laticephalus (Shiogaki \& Dotsu 1971),
Gobiesox marmoratus (Mongard 1981), G. rhessodon (Wells 1979), Lepadogaster candollei (Gonçalves et al. 1998, Patzner 1999a, Hofrichter \& Patzner 2000), L. lepadogaster (Gonçalves et al. 1998, Hofrichter \& Patzner 2000); (ii) exposed rocky substrates: Chorisochismus dentex (Stobbs 1980), Sicyases sanguineus (Paine \& Palmer 1978, Mongard 1981); (iii) coarse gravel: Gouania wildenowi (Kovacic 1997, Hofrichter \& Patzner 2000); (iv) empty bivalve shells: Apletodon incognitus (Hofrichter \& Patzner 1997), Diademichthys lineatus (Sakashita 1992), Diplecogaster bimaculata (Hofrichter \& Patzner 2000), Gobiesox strumosus (Runyan 1961); (v) sea urchins: Acyrtus rubiginosus and Arcos decoris (Schoppe \& Werding 1996), A. incognitus (Patzner \& Santos 1992, Hofrichter \& Patzner 1997, Patzner 1999b), Dellichthys morelandi (Dix 1969), Diademichthys deversor (Pfaff 1942), D. lineatus (Sakashita 1992), juvenile L. candollei (Patzner 1999a, Hofrichter \& Patzner 2000, personal observation); (vi) crinoids: Lepadichthys caritas (Allen \& Starck 1973), L. lineatus (Fishelson 1966); (vii) steams and 
bulbs of kelp: Apletodon dentatus (Gordon 1983, Breining \& Britz 2000, Hofrichter \& Patzner 2000), Rimicola muscarum (Roland 1978); and (viii) seagrass beds: Acyrtops beryllinus (Gould 1965), A. dentatus (Bini 1968, Almeida 1988, Costa et al. 1994), A. incognitus (Hofrichter \& Patzner 1997, Patzner 1999a), Opeatogenys gracilis (Reina-Hervás \& Nuñez Vergara 1985, Hofrichter \& Patzner 1997, 2000).

The small-headed clingfish, A. dentatus (Facciola 1887), is a small clingfish (SL $\max .=4 \mathrm{~cm}$ ) that occurs from Scotland to the Mediterranean (Briggs 1986) where it is one of the rarest gobiesocids (Hofrichter \& Patzner 2000). The ecology of this species is virtually unknown and only scattered information is available on the association of very few specimens with the brown algae Cystoseira in the Mediterranean (Hofrichter \& Patzner 2000), bulbs of Saccorhiza polyschides in the Atlantic coast of Scotland and France (Gordon 1983, Breining \& Britz 2000), and seagrass beds on the Portuguese west coast and the Mediterranean (Bini 1968, Almeida 1988, Costa et al. 1994). In this paper, the patterns of microhabitat utilization and depth distribution of different ontogenetic stages of $A$. dentatus are investigated.

\section{Material and methods}

The study area is located on the west coast of Portugal at the Arrábida Marine Park ( $\left.38^{\circ} 28^{\prime} \mathrm{N}, 8^{\circ} 59^{\prime} \mathrm{W}\right), 50 \mathrm{~km}$ south of Lisbon. This Marine Park is adjacent to the Arrábida Nature Park on land and the coastline consists mainly of steep calcareous cliffs. The underwater rocky habitats present are highly heterogeneous resulting from the disintegration of the cliffs. At shallow depths, boulder fields occur in some places.

A total of 43 dives on 25 stations were performed along this coast using SCUBA from August 1999 to June 2000. The first dives were aimed at sampling all microhabitats where this species could be found (holes, crevices, caves, isolated stones and boulders, boulder fields, sea urchins and algae). In this region, the kelps Saccorhiza polyschides and Laminaria digitata used to be very abundant (Saldanha 1974), but are now quite rare and short (personal observation). After the identification of the microhabitats where fish were present, a systematic sampling of those microhabitats was initiated. Since no previous data on the ecology of this species was available, the stations chosen represent a random selection of the main rocky habitat types present in the Marine Park.
In each station, sampling started at the interface of the rocky substrate with sand (in this area the extent of the rocky substrate is usually only a few dozen meters wide) and progressed towards shallower depths in a perpendicular direction to the coastline. The microhabitat items where fish were found (boulders and the sea urchins Paracentrotus lividus and Sphaerechinus granularis) were randomly inspected. The size of each item and the depth where it occurred (depth range: $1.5-14.8 \mathrm{~m}$ ) were recorded. For the sea urchins, size refers to shell diameter. Total length (TL) of each fish was estimated to the nearest millimetre by measuring with a caliper topographic marks where the fish had laid. All sizes are TL unless stated otherwise. The colouration patterns were also recorded and closely followed the general substrate colour. Colour patterns of $A$. dentatus varied greatly and are similar to those described by Hofrichter \& Patzner (2000) for A. incognitus.

The presence of juveniles of this species in algal turfs was only found for the first time on 25 May 2000. We collected 21 algal turfs opportunistically in late May and early June 2000. Among these, 13 were of the red algae Gelidium latifolium, one of Gigartina acicularis, six of Codium sp. and one of Halopteris scoparia. Each turf was approximately $30-40 \mathrm{~cm}$ high and formed a unit isolated from other algae. The turfs collected reflect the relative abundance of the main algae present in the sampled habitats at that time. For this microhabitat the depth distribution was not analysed in detail. We collected the algal turfs with plastic bags that were tightly closed underwater. At the surface, the turfs were minutely inspected and each fish was collected, killed with an overdose of the anaesthetic quinaldine and preserved in $70 \%$ alcohol for identification purposes (it is not possible to identify with certainty such small fishes in the field).

Due to the similarity between the genus Apletodon and Diplecogaster and to the recent description of a new species of the genus Apletodon (A. incognitus, Hofrichter \& Patzner, 1997), a small sample of fishes $(n=26)$ were collected for identification purposes in a few preliminary sampling surveys. Fish were collected with the aid of the anaesthetic quinaldine diluted to $1: 15$ with alcohol (Patzner 1999a), killed with an overdose of quinaldine and preserved in $70 \%$ alcohol. All biometric and meristic characters conform to the ones ascribed to A. dentatus (Briggs 1955, Hofrichter \& Patzner 1997). Additionally, since the related species $A$. incognitus is known to be associated 
with sea urchins in intertidal pools at the Azores (Patzner \& Santos 1992), the presence of A. dentatus in pools where the sea urchin $P$. lividus is very abundant was also investigated at another two sites: Mexilhoeiro $\left(38^{\circ} 41^{\prime} \mathrm{N}, 9^{\circ} 26^{\prime} \mathrm{W}\right)$ and São Pedro do Estoril $\left(38^{\circ} 41^{\prime} \mathrm{N}\right.$, $9^{\circ} 22^{\prime} \mathrm{W}$ ). We have chosen these sites because there are no intertidal rocky platforms at the Arrábida coast.

The differences in fish length according to microhabitat and the depth distribution of the microhabitat items where A. dentatus occurred, were evaluated by the Kruskal-Wallis test (Zar 1996). Whenever the test statistics were significant, a posteriori multiple comparisons were performed using the Dunn's test (Q-test). The occurrence of A. dentatus in the two species of sea urchins was assessed by a chi-square test. The Mann-Whitney test was used to compare the size of sea urchins with and without fishes. Finally, the relationships between fish and sea urchin size, fish size and depth where sea urchins were found and sea urchin size and depth, were evaluated by Spearman rank correlations.

\section{Results}

In the microhabitats analysed in this study (see Methods), only boulder fields, sea urchins and algal turfs revealed the presence of A. dentatus. We have inspected a total of 1669 microhabitat items and the number of fish found in each is presented in Table 1.

There was a significant difference in the size distribution of $A$. dentatus in the microhabitats analysed (Kruskal-Wallis ANOVA: $\mathrm{H}(3, \mathrm{~N}=267)=$ 175.71, $\mathrm{p}<0.001)$. The smaller fish occurred in algal turfs, the intermediate in the two sea urchins species, and the larger ones in boulders (algal turfs: mean $=0.70 \mathrm{~cm}$, S.D. $=0.08$, range $=0.48-1.05 \mathrm{~cm}$, $\mathrm{N}=119 ;$ S. granularis: mean $=1.7 \mathrm{~cm}, \mathrm{~S} . \mathrm{D} .=0.80$,

Table 1. Number of Apletodon dentatus present in the microhabitats investigated in this study (boulders, the sea urchins Paracentrotus lividus and Sphaerechinus granularis, and algal turfs) and total number of inspected microhabitat items. The 119 A. dentatus found in the algal turfs are all juveniles (see text).

\begin{tabular}{lcccc}
\hline & Boulders & P. lividus & S. granularis & Algal turfs \\
\hline $\begin{array}{l}\text { A. dentatus } \\
\text { Total number }\end{array}$ & 843 & 99 & 29 & 119 \\
$\begin{array}{l}\text { of inspected } \\
\text { microhabitat }\end{array}$ & & 603 & 202 & 21 \\
items & & & & \\
\hline
\end{tabular}

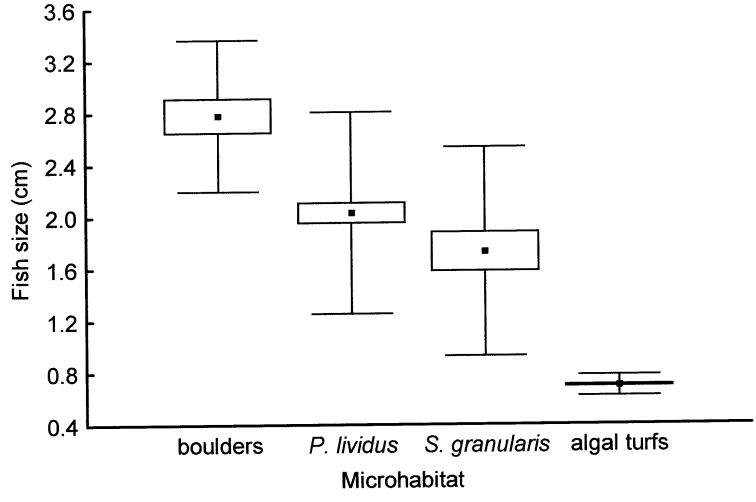

Figure 1. Fish size (cm) distribution (total length) in the microhabitats analysed. All fish found in each microhabitat are included (boulders: $\mathrm{n}=20$; Paracentrotus lividus: $\mathrm{n}=99$; Sphaerechinus granularis: $\mathrm{n}=29$; algal turfs: $\mathrm{n}=119$ ). Small square $=$ mean, box $=$ standard error, lines $=$ standard deviation.

range $=0.5-3.2 \mathrm{~cm}, \mathrm{~N}=29 ;$ P. lividus: mean $=$ $2.0 \mathrm{~cm}$, S.D. $=0.77$, range $=0.5-4.0 \mathrm{~cm}, \mathrm{~N}=99$; boulders: mean $=2.8 \mathrm{~cm}$, S.D. $=0.58$, range $=1.0$ $4.0 \mathrm{~cm}, \mathrm{~N}=20$ ) (Figure 1).

The fish present in the algal turfs were exclusively early recruits with a TL smaller than $1 \mathrm{~cm}$ (with one exception: $\mathrm{TL}=1.05 \mathrm{~cm}$ ). Most fish were associated with the red algae Gelidium latifolium (96\%) and presented a red coloration. For the algal turfs that contained fish, the mean number of individuals found was 8.5 (S.D. $=7.10$, range $=1-21, \mathrm{~N}=14$ ). In the other microhabitats, only a small number of these early recruits $(\mathrm{TL} \leq 1 \mathrm{~cm}$ ) were present (boulders: $\mathrm{n}=1$; $P$. lividus: $\mathrm{n}=18 ; S$. granularis: $\mathrm{n}=10)$.

The larger individuals of $A$. dentatus were associated with boulders (Figure 1). In the last months of the study (May and June 2000) we recorded males with a bright colouration and dark spots on the dorsal and anal fins, which is the breeding colouration pattern (Briggs 1986).

With the exception of the early recruits in algal turfs, most fish occurred in one of the two species of sea urchins (Table 1). In three occasions, we found two and in one occasion three $A$. dentatus under the same $P$. lividus, and in two occasions two A. dentatus under the same $S$. granularis. A total of $16 \%$ of P. lividus and $13 \%$ of $S$. granularis had one or more fish associated.

There was a significant difference in the depth distribution of the sampled microhabitats where individuals of $A$. dentatus were found (Kruskal-Wallis ANOVA: $\mathrm{H}(3, \mathrm{~N}=155)=65.25, \mathrm{p}<0.001)$ (Figure 2). With the exception of algal turfs, the other 


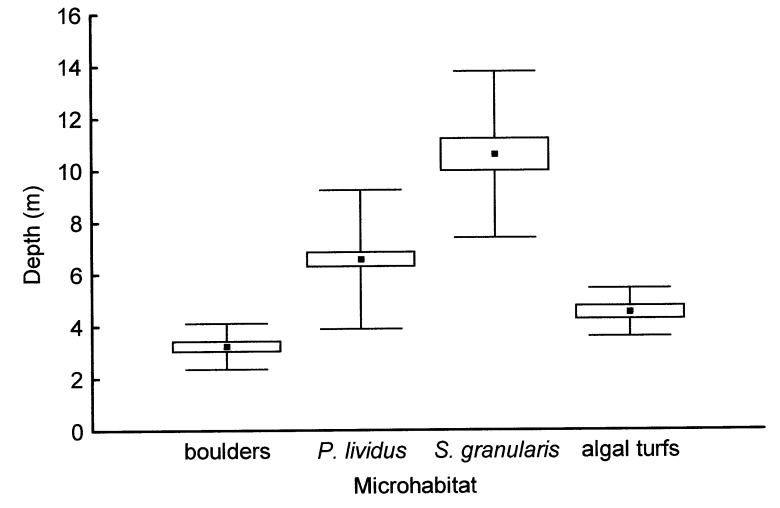

Figure 2. Depth (m) distribution for the microhabitat items analysed. All microhabitat items inspected are included (boulders: $\mathrm{n}=843$; Paracentrotus lividus: $\mathrm{n}=603$; Sphaerechinus granularis: $\mathrm{n}=202$; algal turfs: $\mathrm{n}=21$ ). Small square $=$ mean, box $=$ standard error, lines $=$ standard deviation.

microhabitats were sampled in all depths at which they were found (see Methods). The boulders where $A$. dentatus occurred were located in shallower areas compared to both species of sea urchins (P. lividus: $\mathrm{Q}$-test $=5.24, \mathrm{p}<0.001 ;$ S. granularis: $\mathrm{Q}$-test $=$ 7.73, p < 0.001). S. granularis occurred significantly deeper than $P$. lividus (Q-test $=4.53, \mathrm{p}<0.001$ ).

Concerning the distribution patterns of $A$. dentatus according to sea urchin species, there was no preference for either species of sea urchin in the number of fish present in relation to the total number of sea urchins analysed (chi-square test $=0.81$, d.f. $=1$, $\mathrm{p}=0.37$ ). However, the sea urchins where A. dentatus was found were significantly larger $($ mean $=5.5 \mathrm{~cm}$, S.D. $=1.84$, range $=2.2-10.0 \mathrm{~cm}, \mathrm{~N}=121$ ) than those without fish (mean $=4.6 \mathrm{~cm}$, S.D. $=1.92$, range $=1.0-11.0 \mathrm{~cm}, \mathrm{~N}=604)$ (Mann-Whitney U-test: $\mathrm{U}=32384.5, \mathrm{p}<0.05)$. The fish associated with $P$. lividus did not differ significantly in size from the ones associated with $S$. granularis (Mann-Whitney U-test: $\mathrm{U}=1121, \mathrm{p}=0.073$ ).

Considering only the sea urchins that were associated with fish, fish size and sea urchin size were negatively correlated (Spearman rank correlation: Rs = $-0.258, \mathrm{p}<0.01, \mathrm{~N}=128)$. This was unexpected since larger sea urchins could theoretically provide a greater protection and thus should be preferred by the bigger fish. There was also a negative correlation between fish size and depth for the A. dentatus present in sea urchins (Spearman rank correlation: $\mathrm{Rs}=-0.241, \mathrm{p}<0.01, \mathrm{~N}=128)$. Moreover, the larger sea urchins occurred significantly deeper (Spearman rank correlation: $\mathrm{Rs}=0.565, \mathrm{p}<0.001$, $\mathrm{N}=128$ ). These data suggest that the larger fish associated with sea urchins occur preferentially at shallower depths.

In the tide pools investigated no fish could be found in a total of 80 P. lividus sampled, although three dives performed in the nearby subtidal area revealed the presence of this species associated with sea urchins.

\section{Discussion}

Gobiesocids are in general very small and cryptic fishes that can easily be overlooked. They associate with different types of microhabitats where they seek shelter from predators and/or substrates to breed. The association with sea urchins has been previously described for some species (see Introduction) and the fish can be effectively protected by the sea urchin spines against predators. In some cases, the fish also benefits from the association by feeding on the tube feet and pedicellaria of the sea urchin: e.g. D. deversor (Pfaff 1942) and D. morelandi (Dix 1969).

Until now, A. incognitus and L. candollei were the only two gobiesocids from the north-eastern Atlantic known to be consistently associated with sea urchins (Patzner \& Santos 1992, Patzner 1999b), although we have made an anecdotal comment on the association of A. dentatus with sea urchins in a previous work (Henriques et al. 1999).

Our results suggest that there is an ontogenetic shift in microhabitat utilization by $A$. dentatus with the small juveniles recruiting on algal turfs, the intermediate fish occurring associated with the sea urchins $P$. lividus and $S$. granularis, and the larger individuals mainly present on boulders. These microhabitat shifts have been described for several fishes and can be related with different factors that range from feeding shifts associated with different microhabitat exploitation (e.g. McCormick 1998), spawning site selectivity (e.g. Marliave 1975), different size-related rates of predation (e.g. Werner \& Hall 1988), or even sea water temperature (e.g. Kotrschal 1983). In gobiesocids, there are also some documented cases. In $D$. lineatus the smaller fish never leaves the protection of the spines of Diadema while fish larger than $30 \mathrm{~mm}$ have been seen foraging around corals and the males guard eggs on empty bivalve shells (Sakashita 1992). In L. candollei, juveniles are also mainly associated 
with sea urchins, but the adults occur in several other microhabitats (Hofrichter \& Patzner 2000) and are frequently seen swimming around near the substrate (Gonçalves et al. 1998). For the Mediterranean populations of A. incognitus, the juveniles are also found in sea urchins while the adults occur mainly in bivalve shells (Hofrichter \& Patzner 2000). However, in the Azorean populations of this species, all individuals were found in association with sea urchins, but no adult males were present (Hofrichter \& Patzner 1997), which suggests a possible habitat segregation related to reproduction, with breeding males probably occurring in other microhabitats.

The results presented in this paper suggest that the algal turfs are probably a preferred microhabitat for the settlement of early recruits of $A$. dentatus. In fact, the occurrence of these small juveniles in other microhabitats was rare. It can be argued, however, that the differences found could be due to different predation and/or mortality rates in the different microhabitats. This could probably be true for the boulders which offer little protection. However, in the case of the two species of sea urchins where the juveniles could escape from most predators, the number of juveniles is also low and they were mainly found isolated. This contrasts with the great number of small juveniles found in the algal turfs analysed (see Results).

As fish grow, they seek protection under the spines of sea urchins. For the fish present in sea urchins, fish size and sea urchin size were negatively correlated and the larger sea urchins were found significantly deeper. The larger A. dentatus, some presenting the breeding colouration pattern, were found associated with boulders which are distributed at shallow depths. However, we have not found any eggs. Since the breeding season of this species in our study area is not known, it is possible that we have missed the peak of reproduction. This set of results suggests that reproduction probably takes place in the boulder fields and that the mature fish migrate from the sea urchins to the boulders to breed.

For a small species with parental care of the eggs which are attached to the substrate, it could be advantageous to breed under the protection of the sea urchin spines. However, sea urchins are known to predate fish eggs (e.g. Santos 1995). Moreover, they frequently move away from the shelter places to feed, leaving a nest-attached fish vulnerable to predation. This is probably why the breeding males of clingfishes associated with sea urchins are always found in other microhabitats (e.g. boulders, empty bivalve shells and bulbs of kelp: Gordon 1983, Sakashita 1992, Hofrichter \& Patzner 2000). Further studies focusing on the breeding ecology and recruitment of $A$. dentatus are needed to confirm the shifts in patterns of microhabitat utilization suggested in this paper.

\section{Acknowledgements}

Part of this study was supported by Fundação para a Ciência e a Tecnologia (FCT) through the Pluriannual Program (R\& D Unit 331/94) and as part of the project (PRAXIS-XXI/3/3.2/EMG/1957/95) and by the Instituto da Conservação da Natureza (ICN). The authors would like to thank Ricardo Beldade for reviewing the English, Ricardo Beldade and Jorge Martins for their assistance in the field, and Vítor Almada and two anonymous referees for valuable comments in the manuscript.

\section{References cited}

Allen, G.R. \& W.A. Starck, II. 1973. Notes on the ecology, zoogeography, and coloration of the gobiesocid clingfishes, Lepadichthys caritus Briggs and Diademichthys lineatus (Sauvage). Proc. Linn. Soc. New South Wales 98: 95-97.

Almeida, A.J. 1988. Estrutura, dinâmica e produção da macrofauna acompanhante dos povoamentos de Zostera noltii e Zostera marina do estuário do rio Mira. Ph.D. Thesis, University of Lisbon, Lisbon. 363 pp.

Bini, G. 1968. Atlante dei Pesci delle coste italiane. Mondo Sommerso Editrice 8: 131-132.

Breining, T. \& R. Britz. 2000. Egg surface structure of three clingfish species, using scanning electron microscopy. J. Fish Biol. 56: 1129-1137.

Briggs, J.C. 1955. A monograph of the clingfishes (order Xenopterygii). Stanford Ichthyological Bulletin 6: 1-224.

Briggs, J.C. 1986. Gobiesocidae. pp. 1351-1359. In: P.J.P. Whitehead, M.-L. Bauchot, J.-C. Hureau, J. Nielsen \& E. Tortonese (ed.) Fishes of the North-eastern Atlantic and the Mediterranean, UNESCO, Paris.

Costa, M.J., J.L. Costa, P.R. Almeida \& C.A. Assis. 1994. Do eel grass beds and salt marsh borders act as preferential nurseries and spawning grounds for fish? An example of the Mira estuary in Portugal. Ecological Engineering 3: 187-195.

Daniels, R.A. 1987. Comparative life histories and microhabitat use in three sympatric sculpins (Cottidae: Cottus) in northeastern California. Env. Biol. Fish. 19: 93-110.

Dix, T.G. 1969. Association between the echinoid Evechinus chloroticus (Val.) and the clingfish Dellichthys morelandi Briggs. Pacific Science 23: 332-336.

Faria, C. \& V. Almada. 1999. Variation and resilience of rocky intertidal fish in western Portugal. Mar. Ecol. Prog. Ser. 184: 197-203. 
Faria, C., V. Almada \& M.C. Nunes. 1998. Patterns of agonistic behaviour, shelter occupation and habitat preference in juvenile Lipophrys pholis, Coryphoblennius galerita and Gobius cobitis. J. Fish Biol. 53: 1263-1273.

Fishelson, L. 1966. Contributions to the knowledge of the Red Sea, 36. Preliminary observations on Lepadichthys lineatus Briggs, a clingfish associated with crinoids. Bulletin of the Sea Fisheries Research Station, Haifa 42: 41-48.

Gonçalves, D.M., E.J. Gonçalves, V.C. Almada \& S.P. Almeida. 1998. Comparative behaviour of two species of Lepadogaster (Pisces: Gobiesocidae) living at different depths. J. Fish Biol. 53: 447-450.

Gonçalves, E.J., V.C. Almada, S.P. Almeida, D.M. Gonçalves, M. Repas \& N. Simões. 1996. Observations on the agonistic behaviour of Lepadogaster lepadogaster purpurea (Pisces: Gobiesocidae). J. Fish Biol. 49: 367-369.

Gordon, J.C.D. 1983. Some notes on small kelp forest fish collected from Saccorhiza polyschides bulbs on the Isle of Cumbrae, Scotland. Ophelia 22: 173-183.

Gould, W.R. 1965. The biology and morphology of Acyrtops beryllinus, the emerald clingfish. Bull. Mar. Sci. 15: $165-188$.

Henriques, M., E.J. Gonçalves \& V.C. Almada. 1999. The conservation of littoral fish communities: a case study at Arrábida coast (Portugal). pp. 473-519. In: V.C. Almada, R.F. Oliveira \& E.J. Gonçalves (ed.) Behaviour and Conservation of Littoral Fishes, ISPA, Lisboa.

Hofrichter, R. 1995. Taxonomie, Verbreitung und Ökologie von Schildfischen der Unterfamilie Lepadogastrinae (Gobiesocidae, Teleostei). Ph.D. Thesis, University of Salzburg, Salzburg. $469 \mathrm{pp}$.

Hofrichter, R. \& R.A. Patzner. 1997. A new species of Apletodon from the Mediterranean Sea and the eastern Atlantic with notes on the differentiation between Apletodon and Diplecogaster species (Pisces: Gobiesociformes: Gobiesocidae). Senckenberg. Biol. 77: 15-22.

Hofrichter, R. \& R.A. Patzner. 2000. Habitat and microhabitat of Mediterranean clingfishes (Teleostei: Gobiesociformes: Gobiesocidae). P.S.Z.N. Mar. Ecol. 21: 41-53.

Jones, G.P. 1988. Ecology of rocky reef fish of north-eastern New Zealand: a review. New Zeal. J. Mar. Freshw. Res., 22: 445-462.

Kotrschal, K. 1983. Northern Adriatic rocky reef fishes at low winter temperatures. P.S.Z.N.I. Mar. Ecol. 4: 275-286.

Kovacic, M. 1997. Cryptobenthic gobies (Pisces, Perciformes, Gobiidae) and clingfishes (Pisces, Gobiesociformes, Gobiesocidae) in the Kvarner area, Adriatic Sea. Natura Croatica 6: 423-435.

Lindquist, D.G. 1985. Depth zonation, microhabitat, and morphology of three species of Acanthemblemaria (Pisces: Blennioidei) in the Gulf of California, Mexico. P.S.Z.N.I. Mar Ecol. 6: 329-344.

Marliave, J.B. 1975. Seasonal shifts in the spawning site of a northeast Pacific intertidal fish. J. Fish. Res. Board Can. 32: 1687-1691.

McCormick, M.I. 1998. Ontogeny of diet shifts by a microcarnivorous fish, Cheilodactylus spectabilis: relationship between feeding mechanics, microhabitat selection and growth. Mar. Biol. 132: 9-20.
Miller, P.J. 1979. Adaptiveness and implications of small size in teleosts. Symp. Zool. Soc. London 44: 263-306.

Mongard, R.P. 1981. Desarrollo embrionario y larval de los pejesapos Sicyases sanguineus y Gobiesox marmoratus en la Bahia de Valparaiso, Chile, con notas sobre su reproduccion (Gobiesocidae: Pisces). Investigaciones Marinas Valparaíso 9: $1-24$.

Norton, S.F. 1991. Habitat use and community structure in an assemblage of cottid fishes. Ecology 72: 2181-2192.

Paine, R.T. \& A.R. Palmer. 1978. Sicyases sanguineus: a unique trophic generalist from the Chilean intertidal zone. Copeia 1978: 75-81.

Patzner, R.A. 1999a. Habitat utilization and depth distribution of small cryptobenthic fishes (Blenniidae, Gobiesocidae, Gobiidae, Trypterygiidae) in Ibiza (western Mediterranean Sea). Env. Biol. Fish. 55: 207-214.

Patzner, R.A. 1999b. Sea urchins as a hiding-place for juvenile benthic teleosts (Gobiidae and Gobiesocidae) in the Mediterranean Sea. Cybium 23: 93-97.

Patzner, R.A. \& R.S. Santos. 1992. Field observations on the association between the clingfish Diplecogaster bimaculata pectoralis Briggs, 1955 and different species of sea urchins at the Azores. Z. Fischk. 1: 157-161.

Pfaff, J.R. 1942. On a new genus and species of the family Gobiesocidae from the Indian Ocean, with observations on sexual dimorphism in the Gobiesocidae, and on the connection of certain Gobiesocids with Echinids. Vidensk. Medd. fra Dansk Naturh. Foren. Kobenhaven 105: 413-422.

Reina-Hervás, J.A. \& J.C. Nuñez Vergara. 1985. Opeatogenys gracilis (Canestrini, 1864) (Gobiesocidae, Osteichthyes) en el Mediterráneo Español. Misc. Zool. 9: 405-407.

Roland, W. 1978. Feeding behaviour of the kelp clingfish Rimicola muscarum residing on the kelp Macrocystis integrifolia. Can. J. Zool. 56: 711-712.

Runyan, S. 1961. Early development of the clingfish, Gobiesox strumosus Cope. Chesapeake Sci. 2: 113-141.

Sakashita, H. 1992. Sexual dimorphism and food habits of the clingfish, Diademichthys lineatus, and its dependence on host sea urchin. Env. Biol. Fish. 34: 95-101.

Saldanha, L. 1974. Estudo do povoamento dos horizontes superiores da rocha litoral da costa da Arrábida (Portugal). Arquivos do Museu Bocage - 2a Série 5: 1-382.

Santos, R.S. 1995. Alloparental care in the redlip blenny. J. Fish Biol. 47: 350-353.

Schoppe, S. \& B. Werding. 1996. The boreholes of the sea urchin genus Echinometra (Echinodermata: Echinoidea: Echinometridae) as a microhabitat in tropical South America. P.S.Z.N.I. Mar. Ecol. 17: 181-186.

Shiogaki, M.S. \& Y. Dotsu. 1971. The life history of the clingfish, Conidens laticephalus. Bulletin Fac. Fish. Nagasaki University 32: 7-16.

Shiogaki, M.S. \& Y. Dotsu. 1972. The spawning and the larva rearing of the clingfish, Aspasmichthys ciconiae and the spawning of the clingfish, Aspasma minima. Bulletin Fac. Fish. Nagasaki University 34: 29-34.

Stephens, J.S., Jr., R.K. Johnson, G.S. Key \& J.E. McCosker. 1970. The comparative ecology of three sympatric species of California blennies of the genus Hypsoblennius Gill (Teleostomi, Blenniidae). Ecol. Monogr. 40: 213-233. 
Stobbs, R.E. 1980. Feeding habits of the giant clingfish Chorisochismus dentex (Pisces: Gobiesocidae). South African J. Zool. 15: 146-149.

Wells, A.W. 1979. Notes on the life history of the California clingfish, Gobiesox rhessodon (Gobiesociformes, Gobiesocidae) Calif. Fish Game 65: 106-110.

Werner, E.E. \& D. Hall. 1988. Ontogenetic habitat shifts in bluegill: the foraging rate-predation risk trade-off. Ecology 69 : $1352-1366$.
Zander, C.D. 1980. Morphological and ecological investigations on sympatric Lipophrys species (Blenniidae, Pisces). Helgoländer Meeresunters. 34: 91-110.

Zar, J. 1996. Biostatistical analysis, 3rd edn. Prentice Hall, Englewood Cliffs. 662 pp. 